Genij Ortopedii. 2021. Vol. 27, no. 6. P. 678-685.

\author{
Original article \\ https://doi.org/10.18019/1028-4427-2021-27-6-678-685
}

\title{
Pelvis fixation in posterior ring injuries in polytrauma patients
}

\begin{abstract}
Vladimir I. Kusturov ${ }^{1,2 \bowtie}$, Anna V. Kusturova ${ }^{1,2}$
${ }^{1}$ State Medical and Pharmaceutical University “Nicolae Testemițanu”, Kishinev, Republic of Moldova,

${ }^{2}$ Institute of Urgent Medicine, Kishinev, Republic of Moldova

Corresponding author: Vladimir I.Kusturov, kusturov@mail.ru

Abstract

Background Unstable pelvis injuries are one of the most difficult and severe trauma of musculoskeletal system that needs emergency measures. Aim of the study is the optimization of treatment tactics in unstable pelvis fractures in polytrauma patients. Material and methods This is a prospective study of treatment results of 96 polytrauma patients with unstable pelvic fractures type C. Unilateral injuries of the posterior pelvic ring were $85.42 \%(n=82)$, bilateral injuries were $14.58 \%(n=14)$ of cases. Diagnostic complex included physical examination, laboratory tests, X-rays and CT. Examination was carried out simultaneously with anti-shock measures and intensive care. Primary basic stabilization of the pelvis with an external device and fixation of the posterior ring were performed. Results and discussions Three patients died (3.13\%), the remaining 93 (96.87 \%) patients completed treatment with good outcomes. The biomechanics of pelvic injuries shows us the necessity of external fixation. Unstable pelvis injuries in polytrauma patients with hemodynamic instability should be temporary stabilized to decrease the intrapelvic volume. Conclusions Primary stabilization of the pelvic ring is an effective therapeutic tactic that leads to a significant reduction in the severity of patients' condition, prevention of post-traumatic complications and early functional recovery of the damaged organs.
\end{abstract}

Keywords: polytrauma, pelvis, instability, external fixation

For citation: Kusturov V.I., Kusturova A.V. Pelvis fixation in posterior ring injuries in polytrauma patients. Genij Ortopedii, 2021, vol. 27, no 6, pp. 678-685. https://doi.org/10.18019/1028-4427-2021-27-6-678-685.

\section{INTRODUCTION}

Complex injuries of the pelvic ring are accompanied by rotational and vertical instability [1-5], prolonged bleeding from the vessels of the pelvic bones, soft tissues and major venous plexuses. In combined injuries, bleeding in the abdomen, chest and extremities contributes to the development of shock $[5,6,8]$. The amount of blood loss is a decisive factor in the survival of the injured persons in the early period of traumatic disease [3, 6, 7, 9]. The instability of the pelvic ring is associated with an increase in the internal volume of the pelvis. Closed reduction and stable fixation of the pelvic ring creates a tampon effect and promotes hemostasis [8-10, 13]. Internal fixation [11-17] is accompanied by prolonged surgical intervention, blood loss [6, 9, 18], and subsequently the shock-absorbing function of the pelvis decreases [14, 19, 20].

The purpose of the study was optimization of the tactics in the management of unstable pelvic injuries in polytrauma patients.

\section{MATERIAL AND METHODS}

Treatment results of 96 patients with injuries of the structures of the posterior hemipelvis in polytrauma were analyzed, who accounted for $33.48 \%$ of all 284 analyzed patients with pelvic injuries. Most of the injured persons $(n=83)$ were admitted on the first day after the injury. Diagnostics was carried out simultaneously with anti-shock measures and intensive therapy. The diagnostic complex included clinical and laboratory examination, radiography of six important systems and CT. Patients were familiarized with the Clinic's Charter in order to obtain consent for the inclusion of their data in the research process. In $44.79 \%(n=43)$ of patients, pelvic trauma was combined with chest injury, in $40.63 \%(\mathrm{n}=39)$ with abdominal trauma, damage to the urinary system in $17.7 \%(\mathrm{n}=17)$ and in $23.96 \%$ $(n=23)$ of cases with fractures of the bones of the lower extremities. The injury was caused by road accidents in $59.37 \%(\mathrm{n}=57)$, falling from a height in $33.33 \%$ $(n=32)$ and crushing in $7.29 \%(n=7)$ of the patients. There were 78 men and 18 women among whom $87 \%$ were of working age. The type of pelvic fractures was categorized in accordance with the AO classification: $\mathrm{C} 1$ in $71(73.96 \%)$ patients, C2 in 14 (14.58\%), C3 in $11(11.46 \%)$. Unilateral injuries of the posterior hemipelvis prevailed and were $85.42 \%(\mathrm{n}=82)$, bilateral ones accounted for only $14.58 \%(n=14)$ of cases. In $12.5 \%(n=12)$ of cases, patients had a vertical fracture of the ilium with lateral displacement. Rupture of the sacroiliac joint was observed in $61.46 \%$ $(n=59)$ of cases and was characterized by upward and posterior displacement of the hemipelvis. This group of patients also had pelvic injuries in the anterior region: a rupture of the pubic joint was observed in $34.41 \%$ $(n=34)$ of cases, fractures of the pubic and ischial 
bones in $83.33 \%(n=80)$ of cases. The patients were divided into 3 groups depending on the tactics of pelvic stabilization.

The first group included 54 patients with type $C$ pelvic fractures, cranial displacement of the hemipelvis from 7 to $34 \mathrm{~mm}(22.5 \pm 1.2 \mathrm{~mm}, \mathrm{p}<$ $0.05)$, with multiple rib fractures, mild hemo- and / or pneumothorax. Upon hemo-pneumothorax resolution, primary basic stabilization of the pelvic ring was performed with an external fixation device. Fixation of the posterior half-ring $(n=18)$ was carried out under the control of an image intensifier. Two wires with stoppers were inserted towards each other through the ilium, the sacroiliac joint, the body of the first sacral vertebra, the second sacroiliac joint, and the second iliac bone (Fig. 1). They were attached to the pelvic supports of the device and counter-lateral compression was performed with them.

The second group included 30 patients with $\mathrm{C} 1$ and $\mathrm{C} 2$ pelvic fractures associated with damage to internal organs. The severity of the injury according to ISS was $>25$ points. A prospective study revealed a significantly increased blood loss in this group and an elevated level of interleukin (IL-6 and IL-8) in the blood serum. Primary pelvic stabilization was included in the complex of urgent measures and was performed on the first or second day after the injury. Upon "window of opportunity", a staged osteosynthesis of fractures of the tibia and lower third of the femur $(n=11)$ was performed using the Ilizarov apparatus.

The third group included 12 patients with $\mathrm{C} 3$ pelvic fractures and pronounced response to trauma. The severity of the injury on the ISS scale was $>38$ points. After intensive anti-shock therapy with adequate volumetric compensation of blood loss, the pleural cavities were drained and the rib cage and pelvic ring were stabilized $(n=8)$. During laparotomy $(n=6)$, hemostasis was performed using three "pads" placed on each side of the bladder, below the edge of the pelvis towards the iliac vessels, as well as partial manual reduction of the bones of the anterior hemipelvis and stabilization of the pelvis with an external device $(n=4)$. The posterior hemipelvis was fixed with wires passed through the posterior superior spines of the iliac bones. Final osteosynthesis of the pelvis $(n=6)$ and long bones was performed 7-12 days after injury.

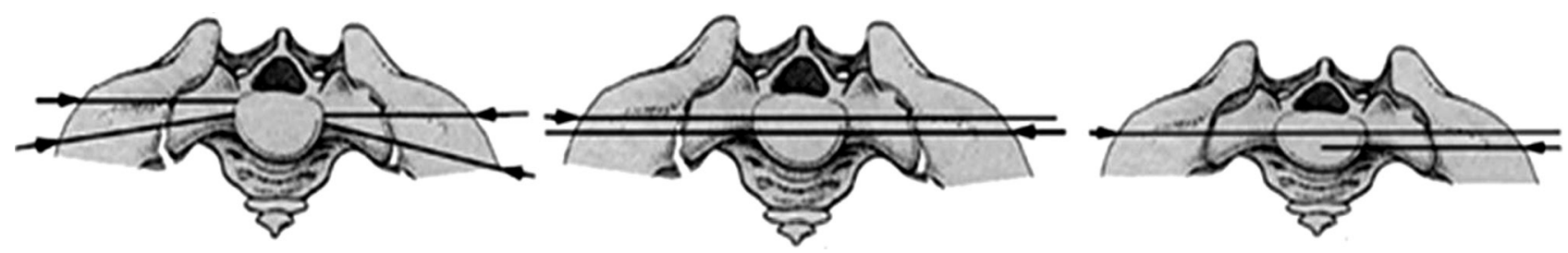

Fig. 1 Diagram of dixation elements insersion in the dorsal part of the pelvis

\section{RESULTS}

Short-term results of treatment were followed up in 96 patients. Three $(3.13 \%)$ patients died. One patient died on the second day after falling from a height. He was admitted with a concussion, "crushed chest," ruptured diaphragm, intestine and bladder injuries, multiple fractures of the limbs and pelvis. The second patient with restored mobility died on the ninth day after injury due massive pulmonary embolism. The third patient was transferred to outpatient treatment on the 24th day after the operation, three days later he died at home. According to the forensic conclusion, the cause was pulmonary embolism, a thrombus formed in the last 24 hours. Most of the remaining 93 patients $(96.87 \%)$ successfully completed treatment. Satisfactory reduction of pelvic bone fragments and stable fixation were achieved on the operating table in $68(70.83 \%)$ patients, the rest underwent long gradual correction. Early fixation of the pelvis stabilized the hemodynamics of patients at a safe level, what ensured a significant decrease in the volume of transfusion blood preparations and a decrease in the number of post-traumatic complications. Expansion of the "X-ray" shadow and increased "blurring" of the contours of the iliac muscle, the development of intestinal paresis was not observed, what indirectly confirmed the tampon effect of early osteosynthesis. After stabilization of the pelvis, the patients could intensify their regimen and worked with a physical therapist. Stabilization of the pelvic bones greatly simplified patient's care, and hypostatic complications were not observed. About $68 \%$ of the patients could independently or with the help get up, moved around, and sat on a chair from the third to the fifth day. Patients with multiple fractures of the pelvis and extremities were less mobile, although they moved within the ward. The duration of inpatient treatment was $28.03 \pm 1.52$ bed-days $(\mathrm{p}<0.05)$.

Stabilization of the pelvic ring in type $\mathrm{C}$ fractures, necessary correction of fragments and stable fixation help to reduce the time of bone union. The period of fixation of the pelvic ring with the device was $59.21 \pm 1.28$ days $(\mathrm{p}<0.05)$. In the following months, the majority of patients $(n=62)$ returned to their usual living conditions and previous work. Nine patients $(9.38 \%)$, whose profession was associated 
with heavy physical work, was assigned a disability group for a year. The duration of social rehabilitation of patients with pelvic fractures after removal of the device was $2-4$ weeks $(22.45 \pm 0.16$ days, $\mathrm{p}<0.01)$, the period of incapacity for work was 2.5-3 months $(79.7 \pm 1.19$ days, $\mathrm{p}<0.05)$. The immediate functional results of treatment were assessed using the S.A. scale. Majeed [21] in 76 patients: a good result of treatment was determined in 39 patients, satisfactory - in 34 patients and unsatisfactory - in three.

Long-term results of treatment were studied in 68 out of 93 patients. The result of the treatment was rated good in 48 cases; in 17 cases it was fair, and in three cases the result of the treatment was assessed as poor. At follow-up after 1.5-2 years, patients complained of dysuric disorders. According to X-ray data, deformity in the pelvic girdle was not determined.

Case report 1. A 16-year-old patient L. was hit by a car. The ambulance took him to the surgical department of the district hospital where he received primary surgical treatment of the forehead wound and symptomatic therapy. Despite the medical measures performed the general condition of the patient deteriorated. He was delivered to the Institute of Emergency Medicine 16 hours after the injury. On admission, the patient's condition was severe: he was conscious, inhibited and did not remember the circumstances of the injury, complained of abdominal pain on the left, was unable to move his legs and experienced sharp pain bending his knees. The skin and visible mucous membranes were pale. The face was symmetrical, the pupils were identical and reacted to light, no focal neurological symptoms were detected. Breathing was vesicular, there was no wheezing, the breathing rate was 24 per min. Heart tones were loud, clear, the rhythm was adequate, tachycardic, pulse 106 beats per min. Blood pressure measured 70/50 mm $\mathrm{Hg}$. The abdomen was well-shaped, tense and painful on the left and at the bottom. The peritoneum irritation symptom was positive, percussion sound being short, the Pasternatsky symptom was sharply positive on the left. Transmission pain was clearly defined with axial load on the pelvis localized at the right iliac wing, pubic symphysis and at the right sacroiliac joint. Catheterization of the bladder was performed, $80 \mathrm{ml}$ of urine with blood obtained. Blood test: hemoglobin - $99 \mathrm{~g} / \mathrm{l}$, erythrocytes $-32 \times 10^{12} / 1$, leukocytes $-12.4 \times 10^{9} / 1$. Urine analysis: protein - $0.28 \mathrm{~g} / 1$, leukocytes $-20-30 \mathrm{HPF}$, erythrocytes - all HPF. A comprehensive physical, radiological and laboratory examination of the patient indicated severe combined trauma: closed craniocerebral trauma, concussion of the brain, lacerated forehead wound; chest contusion, fracture of the V-VI-VII ribs on the left; closed abdominal injury and injury to the spleen, intra-abdominal bleeding; closed retroperitoneal injury and injured left kidney, extensive retroperitoneal hematoma, fracture of pelvic bones type C (Fig. 2), shock grade II-III.

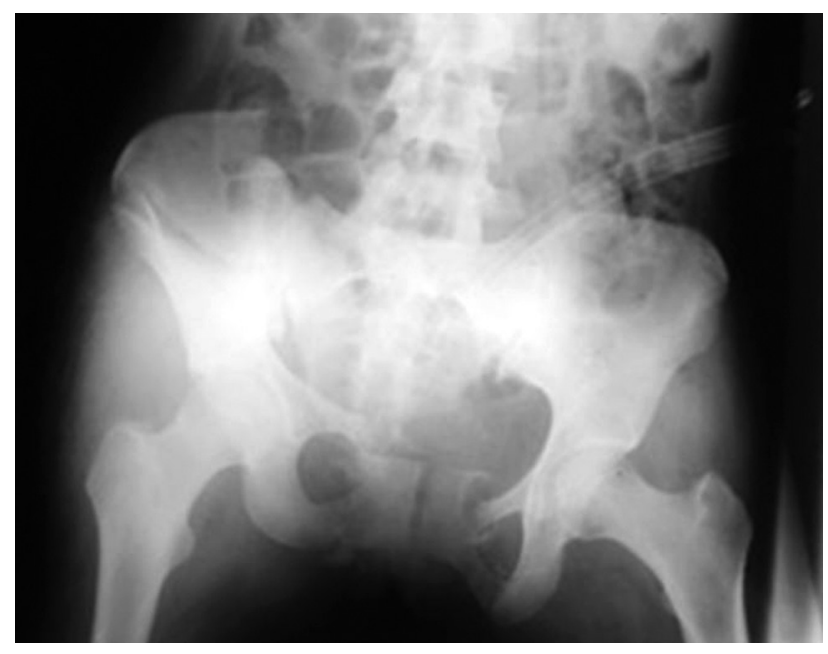

Fig. 2 Radiograph of the pelvis (AP view) of a 16-year-old patient L. diagnosed with polytrauma, pelvic fracture type C, vertical displacement on the right

Laparotomy and splenectomy were performed under general anesthesia. Repeated revision of the abdominal cavity revealed extensive retroperitoneal hematoma and subcapsular rupture of the parenchyma of the left kidney without penetration into the calyx and pelvis that was confirmed by intravenous urography. Pelvic was stabilized after minimal manual reduction of the anterior half-ring before closing the wound of the anterior abdominal wall. There was no drain discharge from the abdominal cavity, and drains were removed after three days of laparotomy. Definitive closed osteosynthesis of the pelvic ring was performed after eight days to include fracture reduction with iliac wings additionally fixed. Two opposing olive wires were placed in the iliac bone, sacroiliac joint, sacral vertebral body, second sacroiliac joint and second iliac bone using image intensifier. The wires were used for sideto-side compression (Fig. 3). The ends of the wires were fixed to z-shaped brackets (Fig. 4).

The next day the patient could sit on the bed with the help of a physical therapist with his legs down on the floor and he could stand using crutches at the end of the day. CBC 11 days after surgery; hemoglobin - $126 \mathrm{~g} / \mathrm{l}$, erythrocytes $-4.0 \times 10^{12} / 1$, leukocytes $-12.9 \times 10^{9} / 1$. Urine test: no protein, leukocytes $12-15 \mathrm{HPF}$, no erythrocytes. The patient stayed at the hospital for 16 days and was discharged to receive outpatient treatment at the place of residence. He was re-admitted after 60 days to get a clinical test for consolidation of the pelvic fracture with the external fixation device destabilized for three days. Physical and radiological assessment showed consolidated pelvic fracture and the possibility to have the frame off. The result of the treatment was rated as excellent on the Majeed grading scale with 80 points. The long-term result was available at 1.5 years (Fig. 5): the patient had no complaints and lameness with full ROM in the hip joints, pain free. The function of the pelvic organs was normal. $\mathrm{CBC}$ and biochemistry panel and common urine test were within normal limits. 


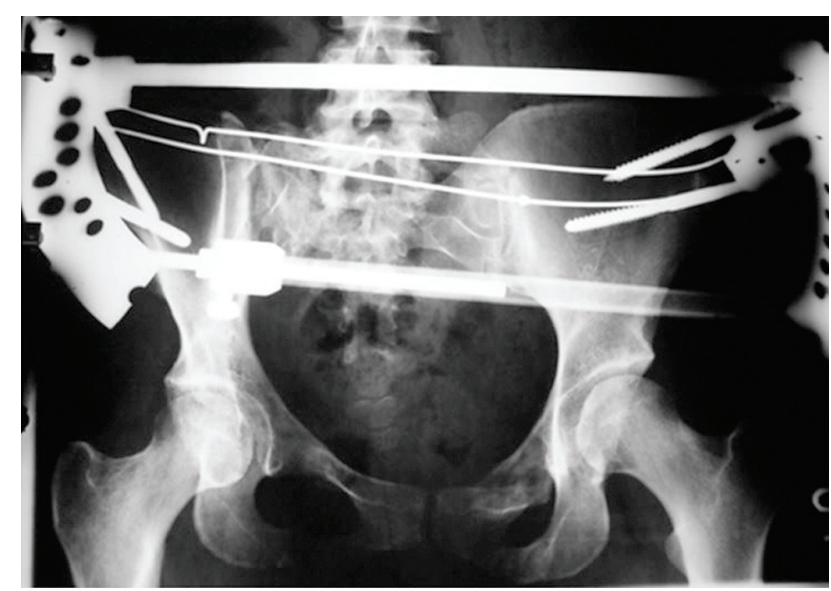

Fig. 3 Radiograph of the pelvis (AP view) of a 16-year-old patient L. diagnosed with polytrauma, pelvic fracture type C. Condition after closed reduction and external fixation

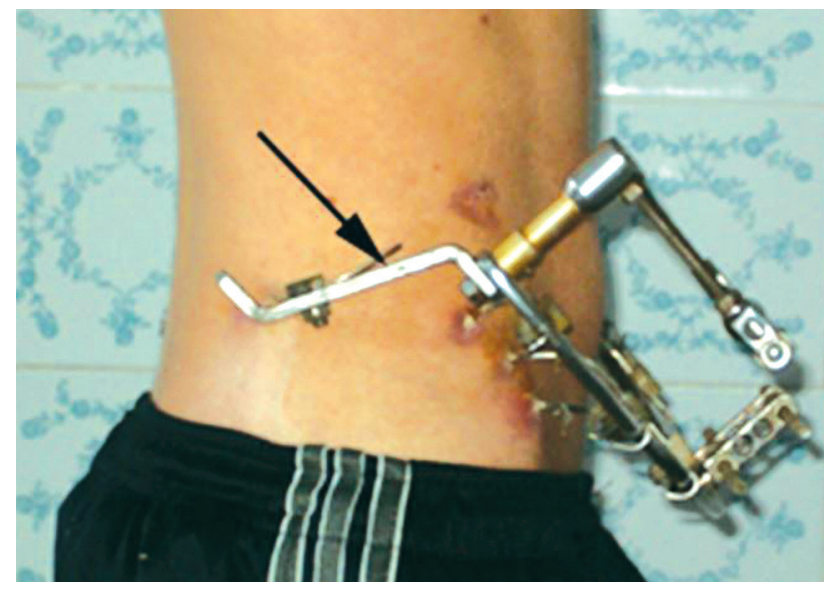

Fig. 4 Photograph of the 16-year-old patient L. with external fixation device mounted to the pelvis. The arrow indicates the $\mathrm{z}$-shaped bracket and the ends of the wires that fixed the dorsal portion of the pelvis

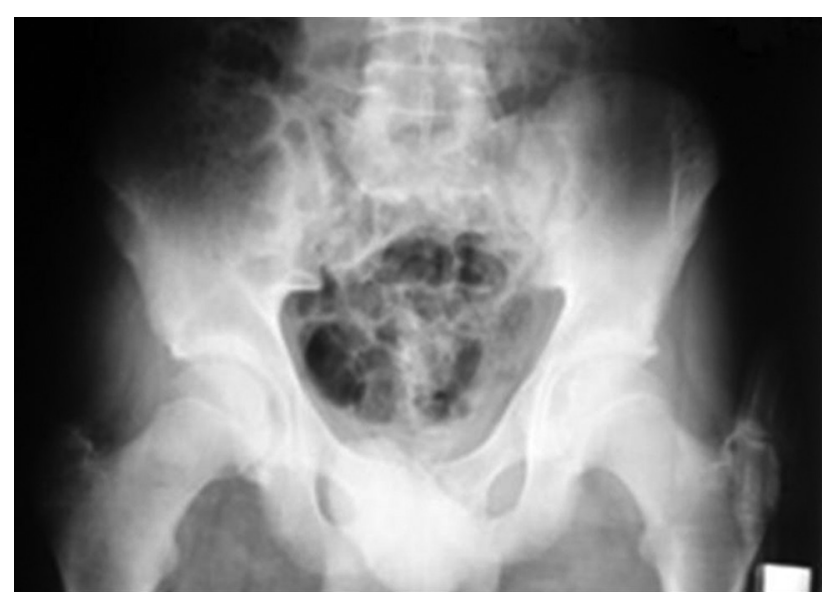

Fig. 5 Radiograph of the pelvis (AP view) of the 18-year-old patient L. at a long term

Case report 2. A 29-year-old patient P. lost control of the motorcycle and crashed into a tree. He was admitted 2.5 hours after the injury and diagnosed with polytrauma: craniocerebral injury with an open fracture of the left temporal bone, otoliquorrhea; closed chest injury, multiple rib fractures (IV, V, VI, VII, VIII) and total pneumothorax on the left (Fig. 6); closed abdominal injury, bladder contusion; open injury to the pelvic ring type $\mathrm{C} 1$ (Fig. 7), rupture of the sacroiliac joint on the left with vertical displacement, fracture of the anterior halfring and rupture of pubic syndesmosis with a divergence of the pubic bones by $5.4 \mathrm{~cm}$, damage to the lymphatic basin, lymphorrhea; closed comminuted fracture of both forearm bones on the left, traumatic shock grade II-III.

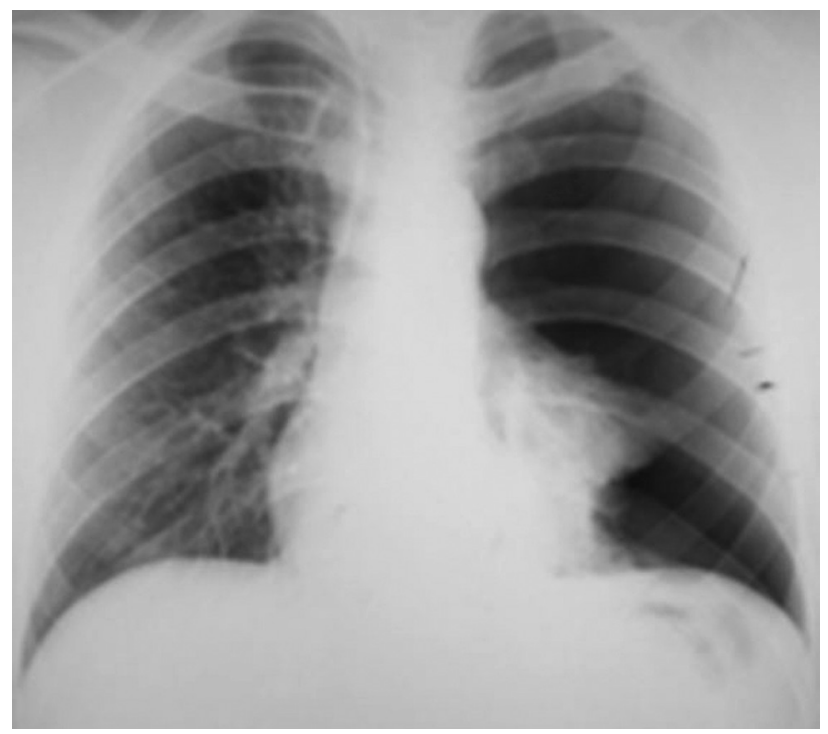

Fig. 6 Radiograph of the chest of a 29-year-old patient P. diagnosed with polytrauma, open pelvic ring injury type C. Closed chest injury, multiple rib fractures on the left, total pneumothorax on the left
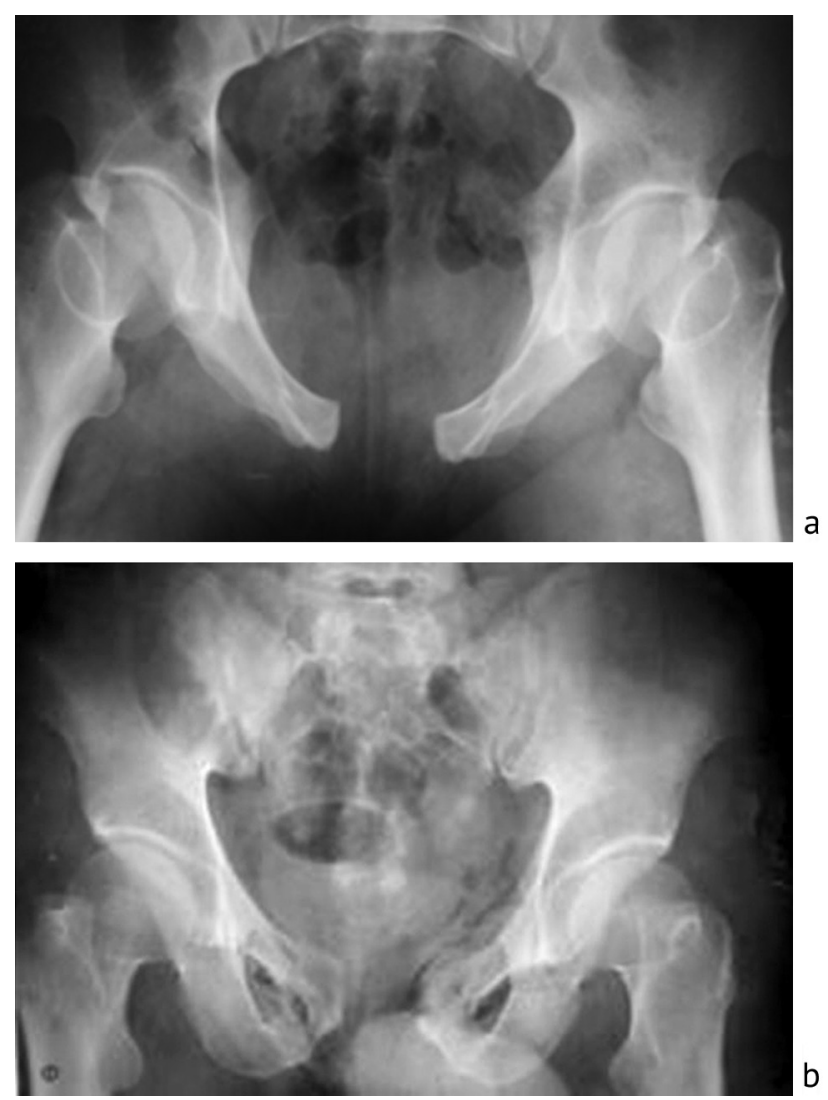

Fig. 7 Radiograph of the pelvis of a 29-year-old patient P. diagnosed with polytrauma, open pelvic ring injury type $\mathrm{C}$ : (a) AP view; (b) caudal view 
A comprehensive examination performed included radiography of the skull, chest, pelvis (AP and caudal views), left forearm, ultrasound assessment of internal organs. Drainage of the left pleural cavity was performed under local anesthesia using the second intercostal space along the midclavicular line and the seventh intercostal space along the middle axillary line at the Bulau point. Primary surgical treatment of temporal wounds on the left and the ilio-inguinal site on the right was performed, and the pelvic ring stabilized with a device for reduction and fixation (Fig. 8). The right lower limb was placed on Beler splint. The left forearm bones were reduced in a closed manner and immobilized with a plaster cast. The lung recovered a day after drainage of the pleural cavity on the left with about $280 \mathrm{ml}$ of serous hemorrhagic fluid released. The bandage at the right groin site was moderately soaked with blood.

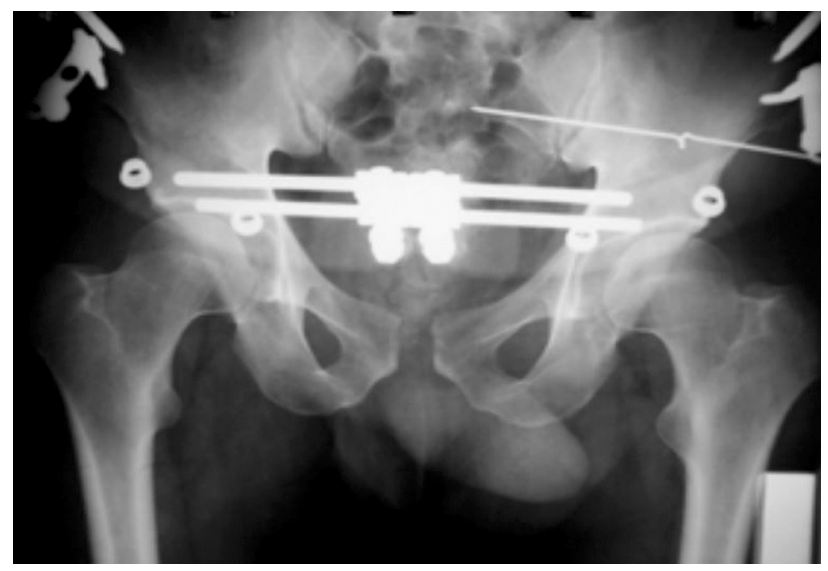

Fig. 8 Radiograph of the pelvis of a 29-year-old patient P. diagnosed with polytrauma, open pelvic ring injury type $\mathrm{C}$. Pelvis stabilized with external fixation device

Four days later, the drains were removed from the pleural cavity. Vesicular breathing was weak with a harsh bronchial breaths on the right. The abdomen was adequately shaped, soft, not enlarged, peristalsis was active. Diuresis was sufficient. The bandage at the right groin site was abundantly soaked with wound discharge. Opalescent viscous liquid of light yellow color released from the wound with dressings changed. On the seventh day, the patient was taken back to the operating room. The ilio-inguinal wound on the right was debrided again. A lymphatic basin was isolated: partial longitudinal injury to the vessel wall was detected that was sutured and additionally tamponed with soft tissues. The wound healed in the postoperative period uneventfully by primary intension (Fig. 9).

The definitive osteosynthesis of the pelvis was also performed using an olive wire placed in the iliac bone on the left, the sacroiliac joint, the sacral vertebra fixed to the pelvic support for compression. Pelvic injury was reduced and stabilized with compression- distraction manipulations using the external fixation device. Closed reduction of the left forearm bones was performed with the Ilizarov apparatus (Fig. 10). Three days later, the patient could stand unassisted using crutches and walk around the ward (Fig. 11). He became an outpatient after 22 days of injury. Fixation of the pelvic bones with the device on lasted 64 days. The patient could walk with full weight-bearing without auxiliary means of support after removal of the frame. He had full ROM in the joints. Fixation of the left forearm bones lasted three months. The outcome was rated as excellent with 86 points on the Majeed scale at one-year follow-up. The patient had no complaints. He could sit freely and walk without a limp. The function of the pelvic organs was restored. He could return to his previous job.

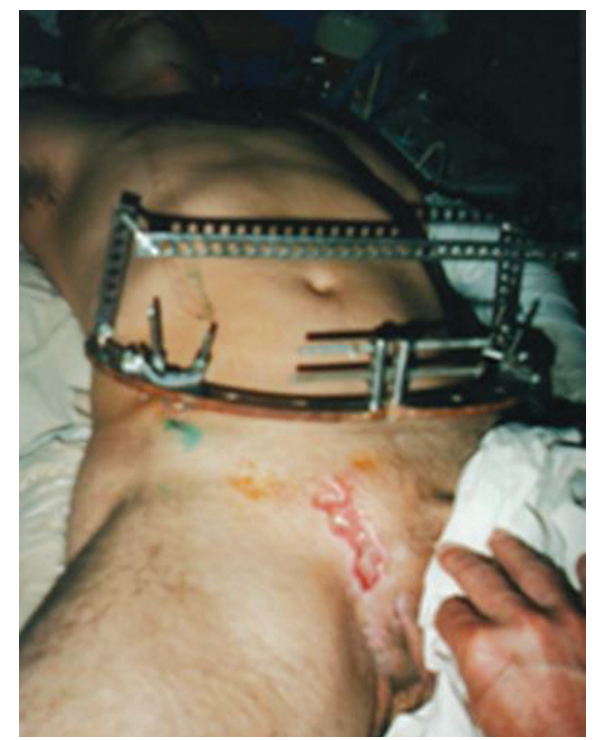

Fig. 9 Photograph of the 29-year-old patient P. diagnosed with polytrauma, open pelvic ring injury. Pelvis stabilized with external fixation device. Re-debridement of the granulating ilioinguinal wound
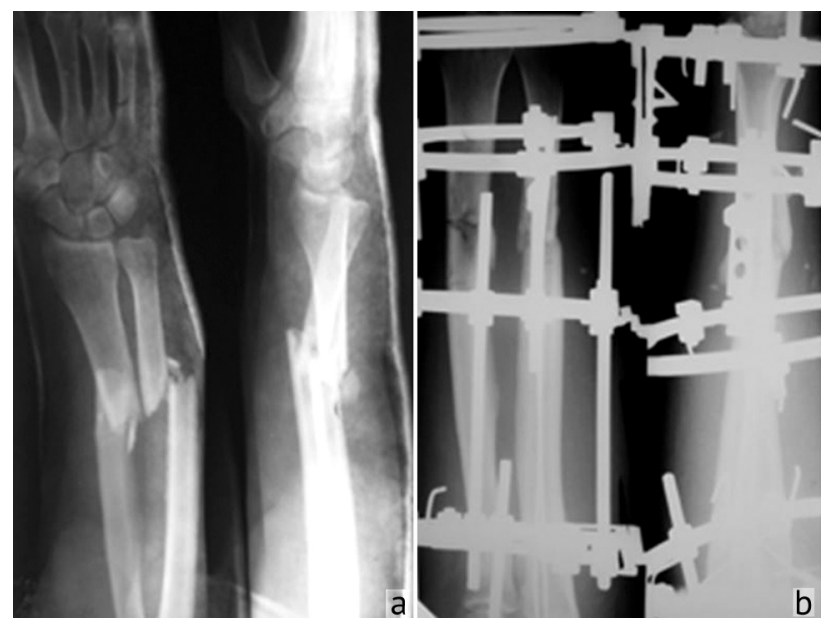

Fig. 10 Radiographs of the left forearm of the 29-year-old patient P. diagnosed with polytrauma, open pelvic ring injury type C, closed comminuted fracture of both forearm bones: (a) preoperatively; (b) forearm bones fixed with the Iliarov frame 


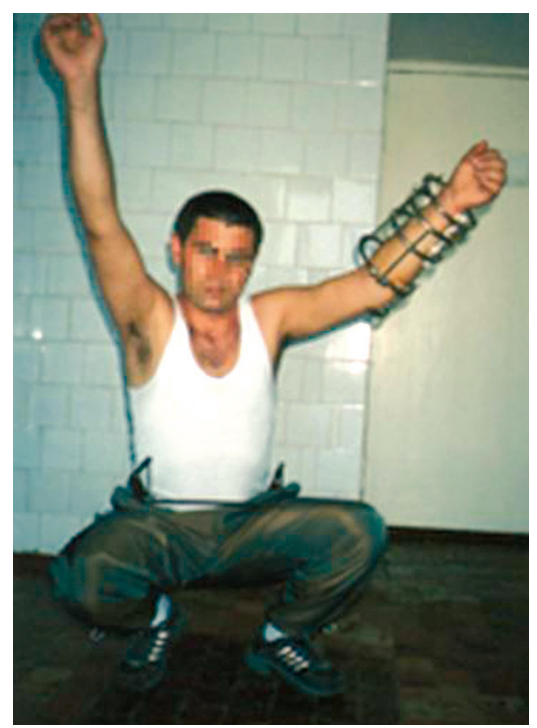

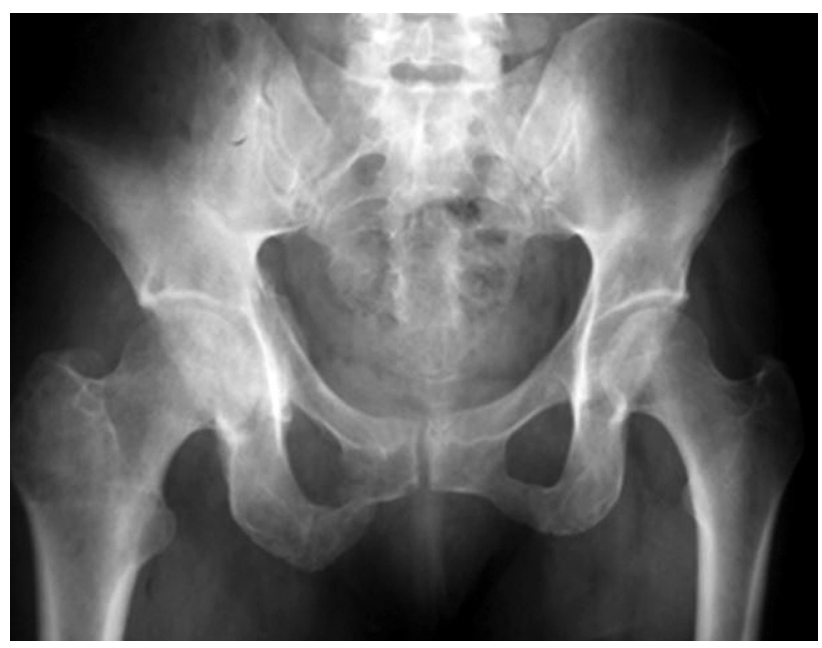

Fig. 12 Radiograph of the pelvis, AP view of the former patient P., 41 years old at 12 years after injury

\section{DISCUSSION}

Posterior pelvic ring fractures type $\mathrm{C}$ can be associated with mortality rate of 40 to $60 \%$ if specialized surgical treatment is not provided within the "golden hour" [22, 23, 24]. The main cause of death in the first 24 hours of a pelvic injury is severe traumatic shock and exsanguination [24, 25]. Injury to the intraosseous vessels and venous plexuses results in retroperitoneal hematoma for 72 hours or more, and if pelvic stabilization is not performed secondary bone displacement can cause more severe bleeding than that at baseline. External fixation of the pelvic ring using transosseous devices applied in the first hours after injury can be a life-saving intervention. Bleeding control is to be provided on admission for fractures types B and C to close the "open book" and temporarily fix the sacroiliac joint with an external fixation device as an excellent tool. Internal fixation is contraindicated on the first day of the injury as recommended by orthopaedic "damage control" [26, 27, 28]. Although external fixation is practical for polytrauma patients due to less invasive procedure, the use at an early stage of traumatic illness and in open fractures, fast performance and reliable fixation $[29,30]$ adequate placement of rods, reduction, in maluniting fractures, in particular can be challenging for unstable posterior fixation. Bulky constructs [5, 29, 30,31], continuous forced positioning of the patient with frame on to have the fracture completely consolidated, high rate of complications and a low quality of life make external fixation with rods unpopular among trauma surgeons [17, 29, 30, 32]. Open reduction and internal fixation has significant benefits for pelvic injuries with the possibility of anatomical reduction and repair of nerve roots, control of fixation stability, early postoperative mobilization without the use of skeletal traction or external devices. However, internal fixation can be applied with completely stabilized hemodynamics, external respiration to be provided within a certain period of time in patients with severe combined chest injury even with the use of modern tools Matta Pelvic System [33], Pelvic Reconstruction System [34]. In addition to that, classical surgical approaches to pelvic fractures are associated with extensive exposure and devascularization of injured bone tissue and pose serious problems for fracture consolidation and postoperative wound healing. P.H. Naude et al. reported the infection rate of $27 \%$ with open approaches [35]. Exposure of fracture sites is often associated with drainage of intra-pelvic and retroperitoneal hematomas and results in secondary bleeding and uncontrolled hemodynamics $[9,13,34]$.

Percutaneous fixation of dislocated sacroiliac joints, fractures-dislocations and fractures of the sacrum with screws with the Routt M. technique is a less traumatic surgical intervention[34, 35, 36]. However, the method is technically demanding and is often accompanied by inadequately placed screws, nerve injury and inaccurate posterior reduction. According to some specialists $[34,35,36]$ and our clinical experience, most difficulties and complications are encountered with early use of this technique. Stabilization of the pelvic ring on admission and in the first two days after the injury are most favorable for the course of the early period of traumatic disease in polytrauma patients. External fixation allows transportation of patients from district to tertiary hospitals, investigations and procedures with pelvis fixed and minimal risk of severe complications. Patients with pelvic fractures, mostly young individuals, have a high overall injury severity score (ISS). The complication rate is still high at the early stages of traumatic disease treated conservatively in patients with hemodynamic instability due to rapid exsanguination, difficulty in achieving hemostasis in 
combined injuries $[8,13,19]$. Based on the extensive clinical experience of our Clinic and positive outcomes achieved we can suggest that minimally invasive technologies with external fixation devices using wires developed by G.A. Ilizarov and improved by his followers appeared to be most effective for stabilizing the pelvic ring. Two olive wires used for iliac-sacroiliac fixation for side-to-side compression were shown to provide more reliable and stable fixation than the use of iliosacral or spongy screws. The technique was less traumatic with no injury to the articular surfaces, fixing components of a smaller diameter (about $2 \mathrm{~mm}$ ) to allow early tissue healing (2-3 weeks) after removal of wires without pathological changes. Iliosacral screws leave $6-8 \mathrm{~mm}$ channels and can be associated with sacroiliitis requiring conservative treatment. The possibility to restore the functional sustainable recovery of the injured body, address the instability of the pelvic ring with minimal traumatic intervention and provide optimal conditions for the healing of damaged structures at a short term can be the criterion for adequate surgical treatment used.

\section{CONCLUSIONS}

1. Polyfocal unstable pelvic fractures result from polytrauma in $95.27 \%$ of cases and are associated with shock $(72.5 \%)$, blood loss, impaired weight-bearing and dynamic functions.

2. Early stabilization and posterior fixation of pelvic injuries can help decrease the severity to regain function of damaged organs.
3. Surgical treatment of type $\mathrm{C}$ pelvic injuries in polytrauma patients using minimally invasive technology with the Ilizarov method has been shown to be practical for all types of pelvic ring fractures and clinical scenarios.

4 A differentiated approach to the fixation technique and surgical repair of pelvic injuries can improve recovery of the pelvic shape and function.

\section{REFERENCES}

1. Tile M., Helfet D., Kellam J. Fractures of the pelvis and acetabulum. $3^{\text {rd }}$ Edition. Baltimore, Lippincott Williams \& Wilkins, 2003,830 p.

2. Zhao M.J., Liu N., Lin H.S., Xu R.M. [Surgical management of old vertical unstable pelvic fractures]. Di Yi Jun Yi Da Xue Xue Bao, 2005, vol. 25, no. 6, pp. 739-741. (in Chinese)

3. Giannoudis P.V., Pape H.C. Damage control orthopaedics in unstable pelvic ring injuries. Injury, 2004, vol. 35, no. 7, pp. 671-677. DOI: 10.1016/j. injury.2004.03.003.

4. Stelmakh K.K. Lechenie nestabilnykh povrezhdenii taza [Treatment of pelvic unstable injuries]. Travmatologiia i Ortopediia Rossii, 2005, no. 4, pp. 3138. (in Russian)

5. Martel I.I., Menshchikov I.N., Dolganova T.I., Chegurov O.K., Shvedov V.V. Kliniko-mekhanicheskaia otsenka sostoianiia konechnostei posle lecheniia patsientov s perelomami kostei taza apparatom chreskostnogo osteosinteza [Clinical-and-mechanical assessment of the condition of the limbs after treatment of patients with fractures of the pelvic bones with a transosseous osteosynthesis apparatus]. Zabaikalskii Meditsinskii Vestnik, 2019, no. 1, pp. 33-44. (in Russian)

6. Kusturov V., Remizov V., Codrean Iu. Role of early osteosynthesis of extremities in patients with associated trauma. 20 $0^{\text {th }}$ World Congress SICOT. Netherlands, Amsterdam, 1996, pp. 511-512.

7. Diatlov M.M. Povrezhdeniia krovenosnykh sosudov taza pri ego nestabilnykh perelomakh i vyvikhakh u bolnykh s sochetannoi travmoi [Injuries of blood vessels of the pelvis with its unstable fractures and dislocations in patients with concomitant trauma]. Vestnik Travmatologii $i$ Ortopedii im. N.I. Priorova, 1999, no. 2, pp. 27-32. (in Russian)

8. Küper M.A., Bachmann R., Wenig G.F., Ziegler P., Trulson A., Trulson I.M., Minarski C., Ladurner R., Stöckle U., Höch A., Herath S.C., Stuby F.M.; Working Group on Pelvic Fractures of the German Trauma Society. Associated abdominal injuries do not influence quality of care in pelvic fracture - a multicenter cohort study from the German Pelvic Registry. World J. Emerg. Surg., 2020, vol. 15, pp. 8. DOI: 10.1186/s13017-020-0290-x.

9. Borozda I.V., Ganzhurov N.A., Nikolaev R.V. Krovopoteria pri perelomakh taza [Blood loss for fractures of the pelvis]. Amurskii Meditsinskii Zhurnal, 2019, no. 2 (26), pp. 50-60. (in Russian)

10. Kusturov V., Kodrianu Iu. Rannii osteosintez kostei taza u postradavshikh s sochetannoi travmoi [Early osteosynthesis of pelvic bones in victims with concomitant injury]. Diagnostika, lechenie i reabilitatsiia bolnykh s povrezhdeniiami kostei taza. Collection of articles. Ekaterinburg, 1996 , pp. 26-28. (in Russian)

11. Gudz Iu.V., Khomutov V.P., Gataulin R.R. Osteosintez perelomov tazovykh kostei [Osteosynthesis for fractures of the pelvic bones]. Materialy Vserossiiskoi Nauchno-prakticheskoi Konferentsii "Sovremennye metody lecheniia bolnykh s travmami i ikh oslozhneniiami" [Proceedings of the AllRussian Scientific-and-Practical Conference “Modern Methods of Treating Patients with Injuries and their Complications”]. Kurgan, 2006 , pp. 137-139. (in Russian)

12. Ilizarov G.A., Deviatov A.A. Vozmozhnosti chreskostnogo osteosinteza pri lechenii perelomov kostei [Possibilities of transosseous osteosynthesis in the treatment of bone fractures]. Materialy Vserossiiskoi Nauchno-prakticheskoi Konferentsii "Lechenie perelomov $i$ ikh posledstvii metodom chreskostnogo osteosinteza" [Proceedings of the All-Russian Scientific-and-Practical Conference "Treatment of fractures and their Consequences by Transosseous Osteosynthesis Method”]. Kurgan, 1979, pp. 4-8. (in Russian)

13. Kim M.J., Lee J.G., Lee S.H. Factors predicting the need for hemorrhage control intervention in patients with blunt pelvic trauma: a retrospective study. BMC Surg., 2018, vol. 18, no. 1, pp. 101. DOI: 10.1186/s12893-018-0438-8.

14. Lazarev A.F., Solod E.I. Biologichnyi pogruzhnoi osteosintez na sovremennom etape [Biological external osteosynthesis at the present stage]. Vestnik Travmatologii i Ortopedii im. N.N. Priorova, 2002, no. 4, pp. 20-26. (in Russian)

15. Cherkes-Zade D.I. Lechenie povrezhdenii taza i ikh posledstvii [Treatment of pelvic injuries and their consequences]. M., Meditsina, 2006, 192 p. (in Russian)

16. Shevtsov V.I., Shved S.I., Shigarev V.M. Apparat vneshnei fiksatsii v lechenii perelomov kostei taza [An external fixator in treatment of pelvic bone fractures]. Travmatologiia i Ortopediia Rossii, 1995, no. 3, pp. 10-12. (in Russian)

17. Höch A., Pieroh P., Henkelmann R., Josten C., Böhme J. In-screw polymethylmethacrylate-augmented sacroiliac screw for the treatment of fragility fractures of the pelvis: a prospective, observational study with 1-year follow-up. BMC Surg., 2017, vol. 17, no. 1, pp. 132. DOI: 10.1186/s12893-0170330-y.

18. Solod E.I., Lazarev A.F., Petrovskii R.A., Ananin A.V., Abdulkhabirov D.A., Alsmadi Ia.M. Klinicheskii opyt lecheniia perelomov kostei taza na fone osteoporoza [Clinical experience in the treatment of pelvic bone fractures through osteoporosis]. Vestnik Travmatologii i Ortopedii im. N.N. Priorova, 2019, no. 4, pp. 5-11. (in Russian)

19. Abudzhazar U.M., Kilybaev A.K., Alkhodzhaev S.S., Batyrbekova I.N., Bikonurov N.O., Makhanov S.A. Iskhody lecheniia perelomov kostei taza [Outcomes of treatment of pelvic bone fractures]. Vestnik Kazakhskogo Natsionalnogo Meditsinskogo Universiteta, 2015, no. 2, pp. 281-282. (in Russian) 
20. Makurin M.Iu., Vereshchagin N.A., Valuev A.N., Vereshchagina E.N., Garkavyi N.G. Rezultaty lecheniia patsientov starshe 60 let s perelomami kostei taza [Results of treatment of patients above 60 with pelvic bone fractures]. Vestnik Ivanovskoi Meditsinskoi Akademii, 2018, vol. 23, no. 3, pp. 22-26. (in Russian)

21. Majeed S.A. Grading the outcome of pelvic fractures. J. Bone Joint Surg. Br., 1989, vol. 71, no. 2, pp. 304-306. DOI: 10.1302/0301-620X.71B2.2925751.

22. Rommens P.M., Arand C., Hofmann A., Wagner D. When and How to Operate Fragility Fractures of the Pelvis? Indian J. Orthop., 2019, vol. 53, no. 1, pp. 128-137.

23. Zwingmann J., Eberbach H., Strohm P.C., Südkamp N.P., Lauritsen J., Schmal H. Decision-making, therapy, and outcome in lateral compression fractures of the pelvis - analysis of a single center treatment. BMC Musculoskelet. Disord., 2019, vol. 20, no. 1, pp. 217. DOI: 10.1186/s12891-0192583-3.

24. Gokalp M.A., Hekimoglu Y., Gozen A., Guner S., Asirdizer M. Evaluation of Severity Score in Patients with Lower Limb and Pelvic Fractures Injured in Motor Vehicle Front-Impact Collisions. Med. Sci. Monit., 2016, vol. 22, pp. 4692-4698. DOI: 10.12659/msm.898459.

25. Marmor M., El Naga A.N., Barker J., Matz J., Stergiadou S., Miclau T. Management of Pelvic Ring Injury Patients With Hemodynamic Instability. Front. Surg., 2020, vol. 7, pp. 588845. DOI: 10.3389/fsurg.2020.588845.

26. Damage control" management in the polytrauma patient. 2nd Ed. Pape H.C., Peitzman A.B., Rotondo M.F., Giannoudis P.V., editors. Springer, Cham, 2017, 338 p. DOI: 10.1007/978-3-319-52429-0.

27. Burlew C.C., Moore E.E., Stahel P.F., Geddes A.E., Wagenaar A.E., Pieracci F.M., Fox C.J., Campion E.M., Johnson J.L., Mauffrey C. Preperitoneal pelvic packing reduces mortality in patients with life-threatening hemorrhage due to unstable pelvic fractures. J. Trauma Acute Care Surg., 2017, vol. 82, no. 2, pp. 233-242. DOI: 10.1097/TA.0000000000001324.

28. Hermans E., Edwards M.J.R., Goslings J.C., Biert J. Open pelvic fracture: the killing fracture? J. Orthop. Surg. Res., 2018, vol. 13, no. 1, pp. 83. DOI: 10.1186/s13018-018-0793-2.

29. Santolini E., Kanakaris N.K., Giannoudis P.V. Sacral fractures: issues, challenges, solutions. EFORT Open Rev., 2020 , vol. 5, no. 5, pp. $299-311$. DOI: 10.1302/2058-5241.5.190064.

30. Watkins R.J., Hsu J.M. The Road to Survival for Haemodynamically Unstable Patients With Open Pelvic Fractures. Front. Surg., 2020 , vol. 7 , pp. 58. DOI: 10.3389/fsurg.2020.00058.

31. Bushmanov A.V., Konnikov A.I. Otsenka funktsionalnykh kachestv sterzhnevogo apparata vneshnei fiksatsii perelomov kostei taza [Assessment of the functional qualities of the rod device for external fixation of pelvic bone fractures]. Vestnik Amurskogo Gosudarstvennogo Universiteta. Seriia: Estestvennye i Ekonomicheskie Nauki, 2018, no. 83, pp. 14-25. (in Russian)

32. Fil Iu.Ia., Lobanov G.V., Gurev S.E., Zavadskii A., Fil A.Iu. Zamena sposoba osteosinteza pri perelomakh kostei taza u bolnykh s politravmoi [Replacing the method of osteosynthesis for fractures of the pelvic bones in patients with polytrauma]. Travma, 2015, vol. 16, no. 1, pp. 67-71. (in Russian)

33. SPS Matta Pelvic System. Stryker: [booklet]. Available at: https://www.strykermeded.com/media/1644/matta-pelvic-brochure.pdf.

34. Smith W.R., Ziran B.H., Morgan S.J. Fractures of the pelvis and acetabulum. $1^{\text {st }}$ Ed. CRC Press, 2007, 376 p.

35. Naudé P.H., Roche S., Nortje M., Maqungo S. The safety and efficacy of percutaneous sacroiliac joint screw fixation. SA Orthopaedic Journal Summer, 2014, vol. 13, no. 4, pp. 26-29.

36. Sîrghi G., Kusturov V., Caproş N., Ungurean V. Stabilizarea spino-pelvină ca metodă de osteosinteză în cadrul fracturilor pelvine [Spino-pelvic stabilization - method of osteosynthesis in pelvic fractures]. Arta Medica, 2020, vol. 76, no. 3, pp. 79-81. (in Moldavian)

The article was submitted 29.05.2020; approved after reviewing 25.09.2020; accepted for publication 19.10.2021.

\section{Information about the authors:}

1. Vladimir I. Kusturov - Doctor of Medical Sciences, kusturov@mail.ru;

2. Anna V. Kusturova - Candidate of Medical Sciences, anna.kusturova@gmail.com.

The authors declare no conflicts of interest.

The study was supported by the National Research and Development Agency and performed as part of the research projects No. 20.80009.8007.07 and No. 20.80009.8007.11. 